\title{
Inflammation Increases the Distribution of Dorsal Horn Neurons That Internalize the Neurokinin-1 Receptor in Response to Noxious and Non-Noxious Stimulation
}

\author{
Catherine Abbadie, ${ }^{1}$ Jodie Trafton, ${ }^{1,2}$ Hantao Liu, ${ }^{1}$ Patrick W. Mantyh, ${ }^{3}$ and Allan I. Basbaum ${ }^{1}$ \\ ${ }^{1}$ Departments of Anatomy and Physiology, W. M. Keck Foundation for Integrative Neuroscience, and ${ }^{2}$ Program in \\ Neurosciences, University of California San Francisco, San Francisco, California 94143, and 3Molecular Neurobiology \\ Laboratory, Veterans Administration Medical Center, Minneapolis, Minnesota 55417
}

\begin{abstract}
Although the neurokinin-1 (NK-1)/substance $\mathrm{P}(\mathrm{SP})$ receptor is expressed by neurons throughout the spinal dorsal horn, noxious chemical stimulation in the normal rat only induces internalization of the receptor in cell bodies and dendrites of lamina I. Here we compared the effects of mechanical and thermal stimulation in normal rats and in rats with persistent hindpaw inflammation. Electron microscopic analysis confirmed the upregulation of receptor that occurs with inflammation and demonstrated that in the absence of superimposed stimulation, the increased receptor was, as in normal rats, concentrated on the plasma membrane. In general, noxious mechanical was more effective than noxious thermal stimulation in inducing $\mathrm{NK}-1$ receptor internalization, and this was increased in the setting of inflammation. Although a $5 \mathrm{sec}$ noxious mechanical stimulus only induced internalization in $22 \%$ of lamina I neurons in
\end{abstract}

normal rats, after inflammation, it evoked near-maximal (98\%) internalization in lamina I, produced significant changes in laminae III-VI, and expanded the rostrocaudal distribution of neurons with internalized receptor. Even non-noxious (brush) stimulation of the inflamed hindpaw induced internalization in large numbers of superficial and deep neurons. For thermal stimulation, the percentage of cells with internalized receptor increased linearly at $>45^{\circ} \mathrm{C}$, but in normal rats, these were restricted to lamina I. After inflammation, however, the $52^{\circ} \mathrm{C}$ stimulus also induced internalization in $25 \%$ of laminae III-IV cells. These studies provide a new perspective on the reorganization of dorsal horn circuits in the setting of persistent injury and demonstrate a critical contribution of SP.

Key words: allodynia; dorsal horn; hyperalgesia; inflammation; neurokinin; substance $P$
Numerous studies have implicated substance P (SP) in the transmission of nociceptive messages at the level of the spinal cord. SP is synthesized by small-diameter, primary afferent fibers, many of which respond to noxious stimulation and terminate in regions of the spinal dorsal horn that contain neurons responsive to noxious stimulation, including the superficial laminae I and II and to a much lesser extent lamina V (Christensen and Perl, 1970; Hökfelt et al., 1975; Menétrey et al., 1977). Noxious stimulation also evokes the release of substance $\mathrm{P}$ into the spinal cord (Duggan et al., 1988; Kuraishi et al., 1989) and spinal CSF (Yaksh et al., 1980; Tiseo et al., 1990), and iontophoretic application of SP excites nociresponsive neurons in the dorsal horn (Henry, 1976; De Koninck and Henry, 1991). Finally, intrathecal injection of SP evokes behaviors indicative of pain (Hylden and Wilcox, 1981; Cridland and Henry, 1988; however, see Frenk et al., 1988).

Despite this evidence numerous questions remain. It has been surprisingly difficult to block noxious stimulus-evoked pain behavior in normal rats, with selective antagonists of the receptor at which SP acts, the neurokinin 1 (NK-1) receptor (Yamamoto and Yaksh, 1992; Munro et al., 1993; Parker et al., 1993; Yamamoto et al., 1993). To some extent this may reflect there being a prefer-

Received June 9, 1997; revised July 30, 1997; accepted Aug. 6, 1997.

This research was supported by National Institutes of Health Grants DE08973, NS21445, NS14627, and NS23970. C.A. was supported by Bourse de Recherche à l'Étranger, Institut National de la Santé et de la Recherche Médicale, and by Institut UPSA de la Douleur. We thank Dr. J.-M. Gries for help with the statistical analysis.

Correspondence should be addressed to Allan I. Basbaum, Department of Anatomy, University of California San Francisco, Box 0452, San Francisco, CA 94143-0452.

Copyright (C) 1997 Society for Neuroscience $0270-6474 / 97 / 178049-12 \$ 05.00 / 0$ ential release of SP by noxious mechanical stimuli (Duggan et al., 1988; Kuraishi et al., 1989). Another paradox concerns the significant mismatch between the distribution of the NK-1 receptor and the location of SP (Liu et al., 1994; Brown et al., 1995). In particular, although the NK-1 receptor is located throughout the dorsal horn, when we monitored internalization of the NK-1 receptor, which occurs when SP binds the receptor, we only found changes in the superficial dorsal horn, in cell bodies and dendrites of lamina I neurons, and in the dorsally directed dendrites of neurons in lamina III (Mantyh et al., 1995). Although there is evidence that SP activates neurons located in deeper parts of the dorsal horn (De Koninck et al., 1992), our results suggested that when SP is released in the normal animal in response to noxious chemical stimulation (capsaicin) of the hindpaw, it predominantly targets neurons in the superficial dorsal horn.

In the present study we evaluated NK-1 receptor internalization in response to different modalities of noxious stimulation and compared the pattern of internalization in normal rats and in rats with an inflamed hindpaw, a condition associated with significant upregulation of the NK-1 receptor in the dorsal horn (Schäfer et al., 1993; Abbadie et al., 1996). Importantly, inflammation induces a central sensitization of dorsal horn neurons that can be reduced by NK-1 receptor antagonists (Thompson et al., 1994). Because the sensitization is manifest as an increase in spontaneous activity, increased excitability, and enlarged receptive fields of neurons in laminae $\mathrm{I}$ and $\mathrm{V}$, and because SP is more readily detected in deep dorsal horn under conditions of inflammation (Schaible et al., 1990), we hypothesized that noxious stimulus- 
evoked internalization of the NK-1 receptor might occur in a wider distribution of neurons in the setting of inflammation.

\section{MATERIALS AND METHODS}

Experimental animals. All experiments were reviewed and approved by the Institutional Care and Animal Use Committee at University of California San Francisco. Experiments were performed on male Sprague Dawley rats (Bantin and Kingman, Fremont, CA), weighing 230-270 gm. Inflammation was induced by subcutaneous injection, in the left hindpaw, of $50 \mu \mathrm{l}$ of complete Freund's adjuvant (CFA; killed Mycobacterium butyricum suspended in mineral oil, solution at $10 \mathrm{mg} / \mathrm{ml}$ ). Three days after the injection, the rats were stimulated. Because mineral oil injection will induce inflammation (Abbadie et al., 1995), control groups of rats were "intact" rats that received no injection.

All experiments were performed $10-15$ min after the rats were anesthetized with sodium pentobarbital $(40 \mathrm{mg} / \mathrm{kg}$, i.p.). This dose blocked all flexor reflex responses to hindpaw stimulation. The hindpaws of the rats were stimulated $10-15$ min after anesthesia was induced.

Hindpaw stimulation. Both non-noxious and noxious mechanical stimulation were used. The non-noxious mechanical stimulus was brushingapplied to the dorsal surface of the left hindpaw (approximately one brush per second for $2 \mathrm{~min} ; n=5$ in each group). Noxious mechanical stimulation (pinch) was applied to the distal part of one hindpaw with a hemostat for 5,15 , or $30 \mathrm{sec}$ or $2 \min (n=4$ in all groups, except $n=5$ for the intact group stimulated for 2 min, and $n=6$ for the CFA group stimulated for $30 \mathrm{sec}$ ). To what extent the pinch stimulus activated cutaneous, subcutaneous, or joint afferents in the intact and inflamed conditions was not determined. In three rats with inflammation, we applied the 2 min noxious stimulus to the hindpaw contralateral to the CFA injection. For all stimulus conditions in these groups, the rats were perfused $5 \mathrm{~min}$ after the stimulation ended.

To evaluate the receptor selectivity of the NK-1 receptor internalization, we studied the effect of GR 205171A, an NK-1 receptor antagonist (Polley et al., 1997) (kindly provided by Glaxo Wellcome) on pinchevoked receptor internalization. We administered GR 205171A (10 $\mathrm{mg} / \mathrm{kg} ; 1.0 \mathrm{ml}$ in saline, s.c., at the base of the neck) $20-25 \mathrm{~min}$ before the pinch stimulus ( $15 \mathrm{sec} ; n=5$ ). Control animals received an equal volume of saline $(n=5)$. Neither the antagonist nor saline induced internalization of the NK-1 receptor without additional stimulation. In this study the rats were perfused 5 min after the pinch stimulus.

For thermal stimulation, the rat's hindpaw (to just below the ankle) was dipped into a water bath heated to either $45,48,50$ or $52^{\circ} \mathrm{C}(n=4$ in all groups, except $n=5$ for the $48^{\circ} \mathrm{C}$ stimulus in the group of rats with inflammation). The duration of the stimulus was $2 \mathrm{~min}$, and all rats were perfused 5 min after the end of the stimulation.

In a previous report we found that the receptor recycled to the plasma membrane within $60 \mathrm{~min}$ of stimulation (Mantyh et al., 1995). To compare the temporal pattern of recycling in the inflamed and intact groups of rats, in a different experiment we perfused rats 30 or $60 \mathrm{~min}$ or $2 \mathrm{hr}$ after the stimulation ( $n=4$ in all groups). For this study, we used a noxious pinch applied for $2 \mathrm{~min}$; this stimulus produces maximal internalization of the NK-1 receptor in lamina I. In another group of rats we evaluated the functional state of the recycled NK-1 receptor by applying a second stimulus at different times after the first. The first stimulus was a $15 \mathrm{sec}$ pinch of the paw. The same stimulus was then applied one hr after the first. We chose a $15 \mathrm{sec}$ stimulus because it produced profound, but less than maximal, internalization of the NK-1 receptor in the intact rat; thus, we could detect both increases and decreases in the magnitude of internalization after the second stimulus. The rats were perfused 5 min after the second stimulus.

Immunocytochemistry. At the appropriate time, the animals received an additional injection of sodium pentobarbital $(100 \mathrm{mg} / \mathrm{kg}$, i.p. $)$ and were perfused intracardially with $50 \mathrm{ml}$ of $0.1 \mathrm{M}$ PBS followed by $500 \mathrm{ml}$ of $4 \%$ formaldehyde in $0.1 \mathrm{M}$ phosphate buffer $(\mathrm{PB})$. The time between the end of the stimulation and the beginning of the fixative flow was $\sim 7-8 \mathrm{~min}$. After the perfusion, the lumbar spinal cord was removed, post-fixed for $4 \mathrm{hr}$ in the same fixative, and then cryoprotected overnight in $30 \%$ sucrose in $0.1 \mathrm{M}$ PB. Immunostaining was performed on $30 \mu \mathrm{m}$ lumbar spinal cord sections (from L2 to L6 segments) cut in the sagittal plane on a freezing microtome. The tissue sections were incubated for 60 min at room temperature in a blocking solution of $3 \%$ normal goat serum in PBS with $0.3 \%$ Triton X-100 (NGST). The sections were then incubated overnight at $4^{\circ} \mathrm{C}$ in the primary antiserum, diluted to $1: 5,000$. The characteristics of the antiserum, which was directed against the $\mathrm{C}$ terminus of the NK-1 receptor, have been described previously (Vigna et al.,
1994). After the primary antiserum, the sections were washed three times in $1 \%$ NGST and then incubated in indocarbocyanine Cy-3-conjugated goat anti-rabbit IgG (Jackson ImmunoResearch, West Grove, PA; 1:600) for $2 \mathrm{hr}$ at room temperature. Finally, the sections were washed three times in PB, mounted on gelatin-coated slides, dried, and coverslipped with DPX (Electron Microscopy Science).

For electron microscopic analysis of the NK-1 receptors in the setting of inflammation, we studied three rats that had received a hindpaw injection of CFA. Three days after the CFA injection, the rats were deeply anesthetized with sodium pentobarbital $(100 \mathrm{mg} / \mathrm{kg}$, i.p. $)$ and perfused through the ascending aorta with $100 \mathrm{ml}$ of $0.1 \mathrm{M}$ PBS, pH 7.4, followed by a $0.1 \mathrm{M}$ PBS fixative solution containing $4 \%$ formaldehyde, $1 \%$ glutaraldehyde, and $0.1 \%$ picric acid. After the perfusion, the lumbar spinal cord was removed, post-fixed in the same solution for $2-4 \mathrm{hr}$, and washed in $0.1 \mathrm{M}$ phosphate buffer for several hours.

We used a pre-embedding immunogold method (Liu et al., 1994) to localize the receptor. Briefly, $40 \mu \mathrm{m}$ vibratome sections were incubated in $50 \%$ ethanol to improve penetration of the NK-1 receptor antibody. The latter was localized with a $1.0 \mathrm{~nm}$ colloidal gold-conjugated secondary antibody. After the immunoreaction, the sections were silverenhanced and then dehydrated and embedded in plastic. From each animal we analyzed at least nine grids containing two thin sections each. These were collected from three different plastic-embedded vibratome sections through lamina I. Neuronal profiles were considered positive for NK-1 receptors when the density of silver particles was at least three times greater than in surrounding neuropil. To quantify the distribution of NK-1 receptor labeling, we collected photomicrographs through lamina I and counted silver particles. The results are expressed as number of particles per unit length of the plasma membrane or per area of cell bodies and dendrites.

Quantification of NK-1 receptor immunoreactivity and statistical analysis. We only quantified internalization in cell bodies. Dendrites were not analyzed in this study, because the extensive overlap of labeled profiles made it difficult to evaluate endosomal labeling in dendrites, even with confocal analysis. It is particularly difficult to distinguish endosomes in the thin distal dendrites that arborize within lamina I. Based on our previous studies, however, we believe that internalization in cell bodies and dendrites follows the same time course (Mantyh et al., 1995). To analyze internalization in cell bodies we used $20 \times$ and $60 \times$ objectives on a Nikon microscope equipped for fluorescence. We counted all NK-1 receptor-like immunoreactive (LI) cell bodies in laminae I, III-IV, and $\mathrm{V}-\mathrm{VI}$ of the dorsal horn, ipsilateral to the side of stimulation, from segments L2-L6. In cell bodies that do not contain internalized receptors, the immunoreactivity is uniformly distributed on the cell surface, but in the neurons that have internalized the NK-1 receptors, the cytoplasm contained bright, immunofluorescent structures. Unstimulated cells contained less than five endosomes per cell. In the present study we considered a cell to have internalized receptor if it contained $>20$ endosomes. Importantly, because we did not count the number of endosomes if $<20$ were present (i.e., the categorization was all or none), it is possible that we missed subtle changes in the magnitude of internalization.

Because we found no difference in the magnitude of internalization along the mediolateral extent of the superficial dorsal horn, we counted all the cells within one segment, without taking into account the mediolateral position of the cells. All counts were then expressed as the percentage of NK-1 receptor-immunoreative neurons that contained internalized receptor. The investigator who counted the NK-1 receptor-LI cells was unaware of the treatment of the animal.

For statistical analysis, we used a three-way ANOVA for treatment condition (intact vs inflammation), for temperature intensity or duration of the stimulation (for pinch), and for spinal segment (L2-L6 lumbar segments). For multiple comparisons, we used Fisher's protected least significant difference test; $p<0.05$ was considered statistically significant.

In some cases the ANOVA was inappropriate either because of the heterogeneity of variances or because there was a clear difference between the two groups in NK-1 receptor internalization induced by mechanical stimulation (intact and inflamed). For the analysis, therefore, we specifically addressed the shape of the curve of the response of NK-1 receptor internalization in lamina I of the L4 spinal segment, which is the main target of primary afferent fibers from the hindpaw. To evaluate the contribution of duration of the mechanical stimulation $(5-120 \mathrm{sec})$, we performed a two-way ANOVA that compared the differences between the intact rats and the rats with chronic inflammation. Because of differences in responses (percentage of NK-1 receptor internalization as 
a function of stimulus duration) in the two groups of rats, we modeled the responses independently. For the inflamed rats, because the response seems constant, we tested for equality in responses by comparing the one-way (duration) ANOVA with the corresponding linear model. For the intact animals, the data were fitted to the Hill equation using weighted nonlinear regression to account for variance nonhomogeneity in the data (Boeynaems, 1980). This approach takes into account differences in the variances and the ordered relationship of stimulus duration $(5,15,30$, and $120 \mathrm{sec})$. In a second step, the model was tested against a linear model using a Fisher's test based on the residual deviance (i.e., variability of residuals corrected for differences in variances seen in the data). In the study that examined noxious heat-induced internalization, we first performed a two-way ANOVA for effect of treatment condition (i.e., inflamed vs intact) and then for the effect of temperature $\left(45-52^{\circ} \mathrm{C}\right)$. To test for linearity of the relationship, we used a generalized linear model (McCullagh and Nelder, 1989) with temperature as the continuous independent variable and treatment condition as the categorical variable.

Confocal images. Although our quantitative analysis was performed on tissue observed with epi-illuminated fluorescence, to illustrate better the patterns of receptor internalization that were induced in the different treatment conditions, we examined some sections by confocal microscopy. The confocal images described below were collected with an MRC 600 confocal microscope (Bio-Rad, Richmond, CA). Images were then transferred in National Institutes of Health Image (version 1.60), and montages were created in Adobe Photoshop (version 3.0).

\section{RESULTS}

\section{NK-1 receptor-like immunoreactivity in intact and inflamed rats without superimposed stimulation}

As we reported previously (Brown et al., 1995), there is a very distinct pattern of NK-1 receptor-immunoreactive neuronal staining in the dorsal horn of the rat. The densest staining is found in cell bodies and dendrites of lamina I (Figs. 1, 2). The immunoreactivity is best viewed in sagittal section, because the dendrites, which express the bulk of the immunoreaction product, arborize in the rostrocaudal plane (Fig. 1). Lamina II (the substantia gelatinosa) contains very few NK-1 receptor-LI neurons, except for some dorsally directed dendrites of relatively large NK-1 receptor-LI neurons located in laminae III-IV (Fig. 3). Smaller neurons with round cell bodies are also located in laminae III-VI; dendrites of these neurons arborize in all directions and in all planes (Fig. 3). There are also numerous NK-1 receptor-immunoreactive neurons in lamina $\mathrm{V}$; a few of these have dorsally directed dendrites that extend into lamina I. Finally, densely stained, large, round cell bodies are clustered around the central canal (Fig. 4E). In all regions, the NK-1 receptor immunoreactivity is concentrated on the plasma membrane of cell bodies and dendrites.

As reported previously, the density of NK-1 receptor-LI increases significantly in rats with an inflamed hindpaw. This was found in lamina I, not only in the L4 and L5 segments, which receive primary afferent input from the injected hindpaw, but also rostrally, in L1, and caudally, into sacral segments. We also observed an increase in laminae III-V; however, changes in these areas were not analyzed quantitatively. Although afferent input from the hindpaw targets the medial part of the dorsal horn, the upregulation of the NK-1 receptor after inflammation occurs across the mediolateral extent of the dorsal horn. In our previous study (Abbadie et al., 1996) we used an HRP detection method, which is not ideal for light microscopic distinction of membrane and cytoplasmic labeling. In the present fluorescence analysis, we established that the increased receptor labeling after inflammation (in the absence of superimposed stimulation) remains on the membrane. Counts of labeled immunofluorescent neurons also confirmed that the number of substance $\mathrm{P}$ receptor (SPR)immunoreactive neurons did not increase in the rats with inflam-
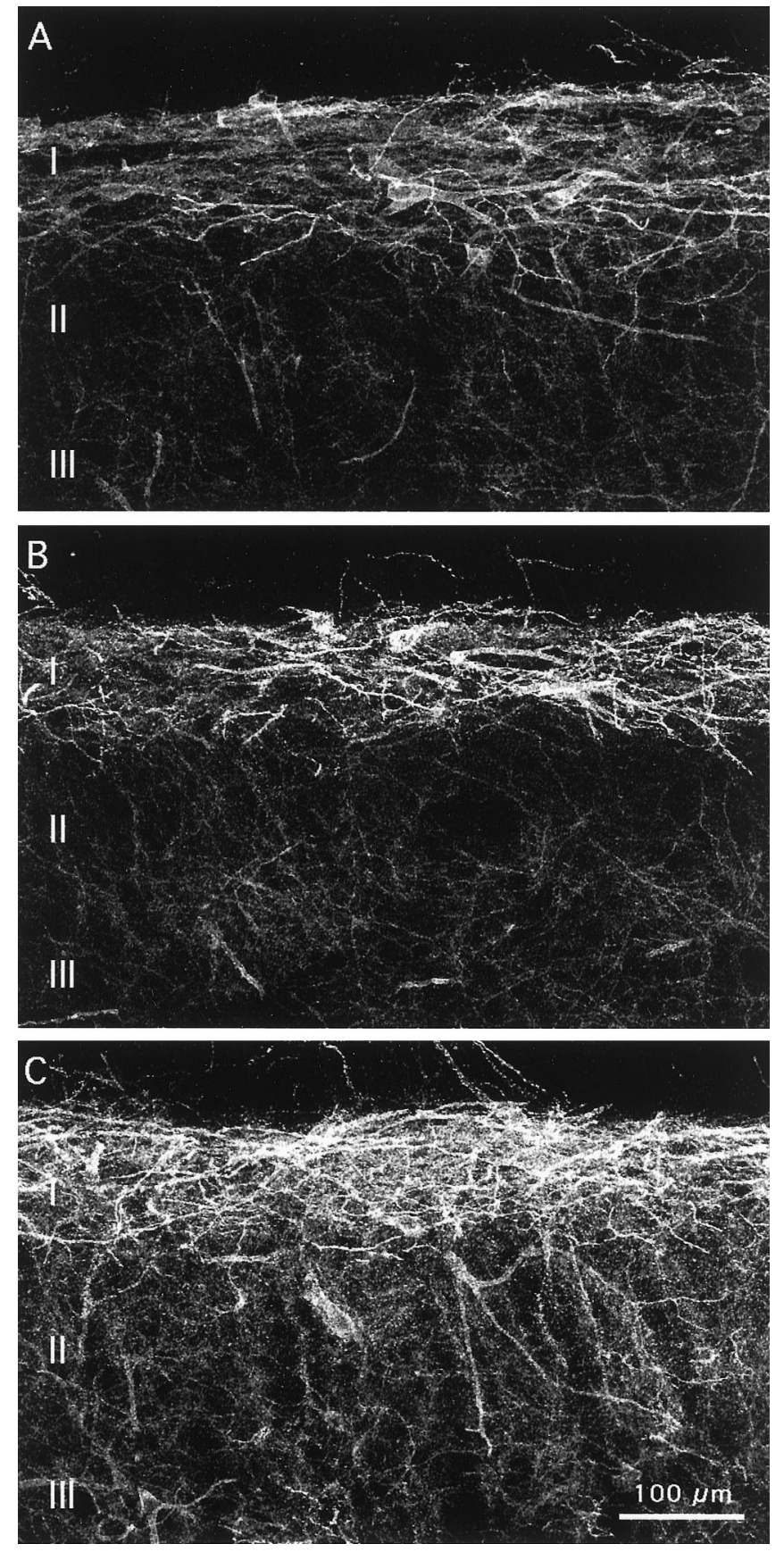

Figure 1. Confocal images illustrating the dorsoventral pattern of internalization of the NK-1 receptor after mechanical stimulation of the hindpaw. These images were generated by superimposition of three optical sections taken at $2.5 \mu \mathrm{m}$ in sagittal sections of L4. A, Rat with inflamed hindpaw with no additional stimulation; the receptor is distributed on the plasma membrane of neurons in laminae I-III. $B$, Intact rat after mechanical stimulation of the hindpaw (pinch for $30 \mathrm{sec}$ ); cell bodies and dendrites in lamina I contain internalized NK-1 receptor; however, no changes were recorded in lamina III. $C$, Rat with inflamed hindpaw after mechanical stimulation of the hindpaw (pinch for $30 \mathrm{sec}$ ). There is extensive receptor internalization in cell bodies and dendrites of neurons throughout the dorsal horn.

mation. For example, in lamina I of L4 segment we found $86.32 \pm$ 5.3 (mean per rat) NK-1 receptor-LI neurons in rats with inflammation and $82.08 \pm 2.1$ in intact rats. This result indicates that the increase in SPR immunoreactivity in the rats with inflammation 

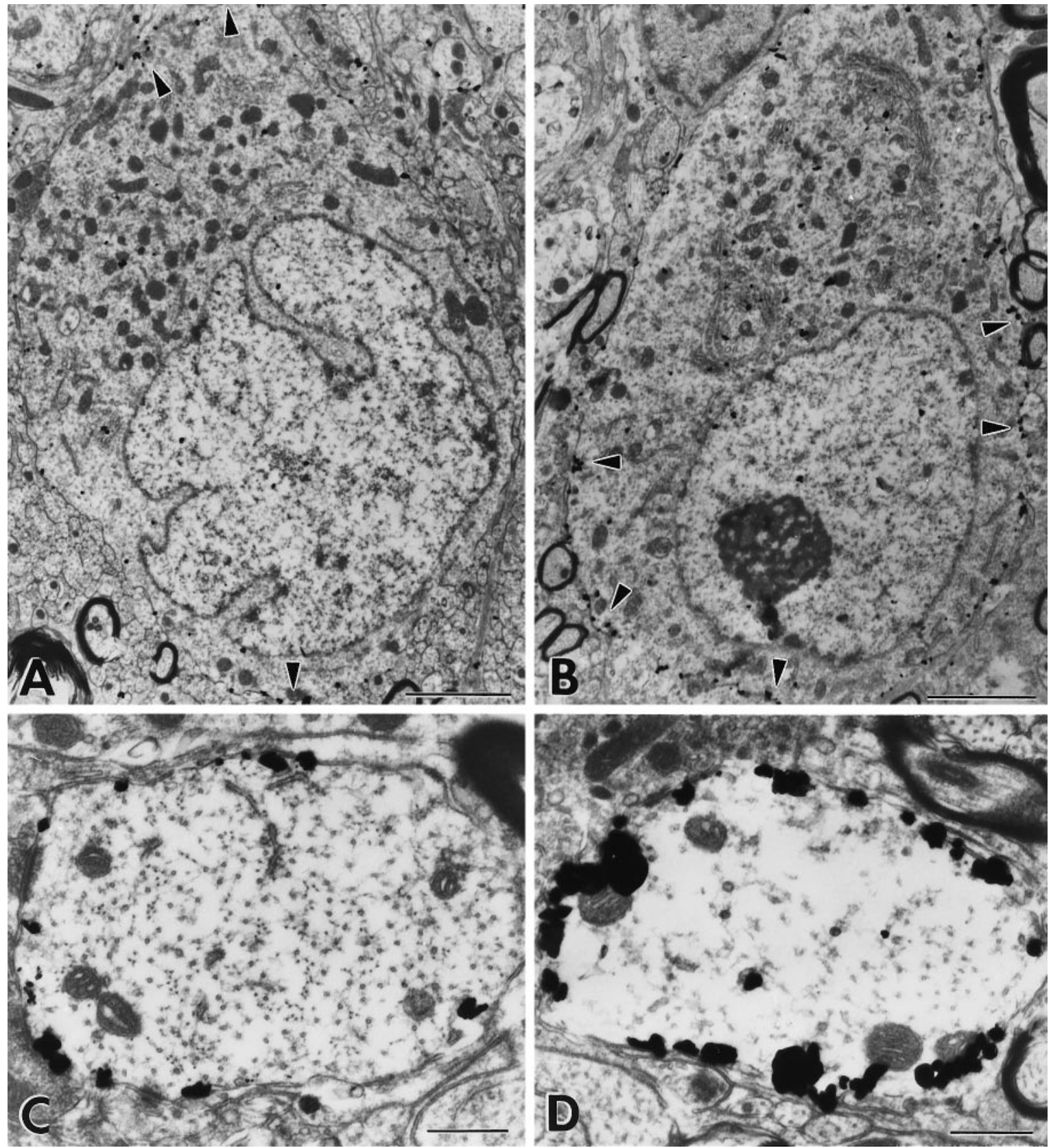

Figure 2. Electron micrographs illustrating the distribution of NK-1 receptor immunoreactivity in neurons of lamina I of the dorsal horn of an intact rat $(A, C)$ and a rat $3 \mathrm{~d}$ after inflammation of the hindpaw was induced with CFA $(B, D)$. In the intact rat the receptor labeling (arrowheads) is concentrated on the plasma membrane of both cell bodies $(A)$ and dendrites $(C)$. After inflammation there is a significant increase in NK-1 receptor immunoreactivity; however, the receptor labeling (arrowheads) is still concentrated on the plasma membrane of cell bodies $(B)$ and dendrites $(D)$. In both cases, there is some cytoplasmic label present. Scale bars: $A, B, 2.0 \mu \mathrm{m} ; C, D, 0.25 \mu \mathrm{m}$.

did not arise from receptor upregulation in neurons that previously did not express the receptor. Rather, it appears to be an increased NK-1 receptor expression in the existing population of NK-1 receptor-immunoreactive neurons.

Quantitative analysis of the electron micrographs from the dorsal horn ipsilateral and contralateral to the CFA injection further established that although there was a 3.1-fold increase in the density per unit area of NK-1 receptor immunoreactivity (Fig. 2), the percentage of total labeling found on the membrane versus the percentage found in the cytoplasm did not differ on the two sides of the cord. In cell bodies, $70.4 \%$ of particles were distributed on the membrane in the ipsilateral side versus $75.6 \%$ in the contralateral side; in dendrites, $79.7 \%$ of particles were distributed on the membrane in the ipsilateral side versus $78.2 \%$ in the contralateral side.

\section{Effects of stimulation in normal rats (without inflammation)}

The number of NK-1 receptor-immunoreactive neurons in sagittal dorsal horn sections varies somewhat along the mediolateral extent of the dorsal horn. In a $30 \mu \mathrm{m}$ section through the L4 segment of the intact rat, we counted $10 \pm 4$ cells in lamina I on one side, $0-5$ cells in laminae III-IV, and $20 \pm 7$ cells in laminae V-VI. Because we never found stimulation-evoked internaliza- 

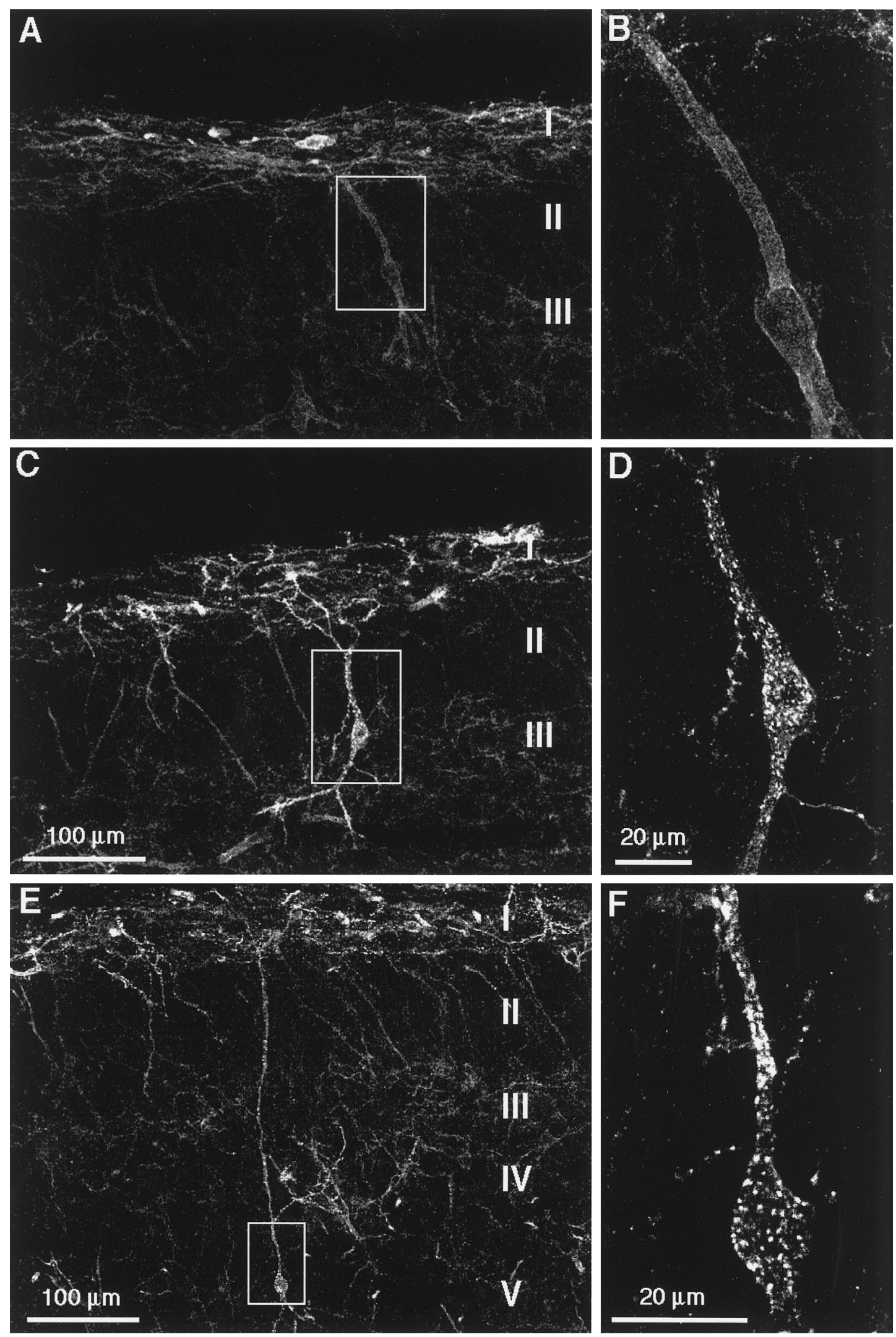

Figure 3. Confocal images illustrating internalization of the NK-1 receptor in neurons of laminae III and V after mechanical stimulation of the hindpaw (pinch for $30 \mathrm{sec}$ ). $A, C, E$ were produced by superimposition of three optical sections taken at $2.5 \mu \mathrm{m}$ in sagittal sections of L4; $B, D, F$ were produced by superimposition of seven optical sections taken at $0.6 \mu \mathrm{m} . A, B$, Intact rat after mechanical stimulation of the hindpaw (pinch for 30 sec); there is no internalization in this lamina III neuron. $C, D$, Rat with inflamed hindpaw after mechanical stimulation of the hindpaw (pinch for 30 sec); there is extensive internalization of NK-1 receptors in this lamina III neuron. $E$, $F$, Same experimental condition as for $C$, $D$; note internalization of NK-1 receptors in this lamina $\mathrm{V}$ neuron. 

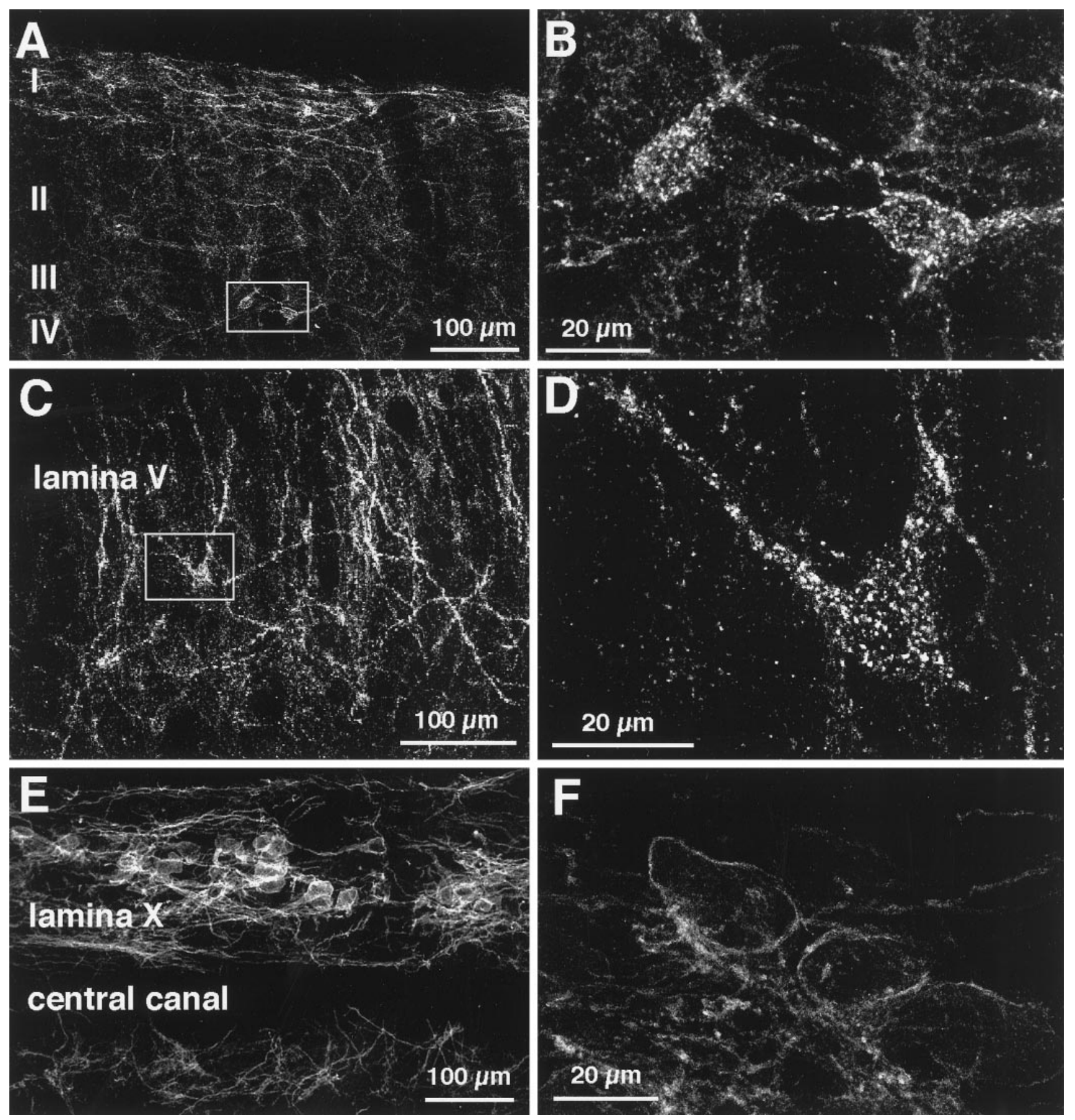

Figure 4. Confocal images illustrating internalization of the NK-1 receptor in neurons of laminae III, V, and X. $A-F$, Rat with inflamed hindpaw after mechanical stimulation of the hindpaw (pinch for $2 \mathrm{~min}$ ). $A, C, D$ were produced by superimposition of three optical sections taken at $2.5 \mu \mathrm{m}$ in sagittal sections of L4; $B, D, F$ were produced by superimposition of seven optical sections taken at $0.6 \mu \mathrm{m}$. There is internalization of NK-1 receptors in laminae III $(A, B)$ and $\mathrm{V}(C, D)$ after mechanical stimulation of rats with persistent inflammation. In intact rats this stimulus only induces internalization in lamina I neurons. Neither mechanical nor thermal stimulation induced internalization in neurons of lamina $\mathrm{X}(F)$.

tion of the NK-1 receptor in neurons of the dorsal horn contralateral to the stimulated hindpaw (even in the setting of inflammation and regardless of modality of the stimulus), the following quantitative analysis is limited to ipsilateral segments.

\section{Mechanical stimulation}

Noxious mechanical stimulation of the hindpaw (pinch) was a particularly effective stimulus for evoking NK-1 receptor inter- nalization in dorsal horn neurons. With the exception of isolated neurons in lamina II, we only found internalization of the receptor in lamina I neurons (Fig. $1 B$ ). We found that the magnitude of receptor internalization (percentage of cells showing internalization) increased with the duration of the mechanical stimulus; the relationship, however, was not linear (Fig. 5). For example, we recorded a significant difference $(p<0.001)$ between the 5 and 15 sec stimuli (22 and $81 \%$, respectively in lamina I of the L4 


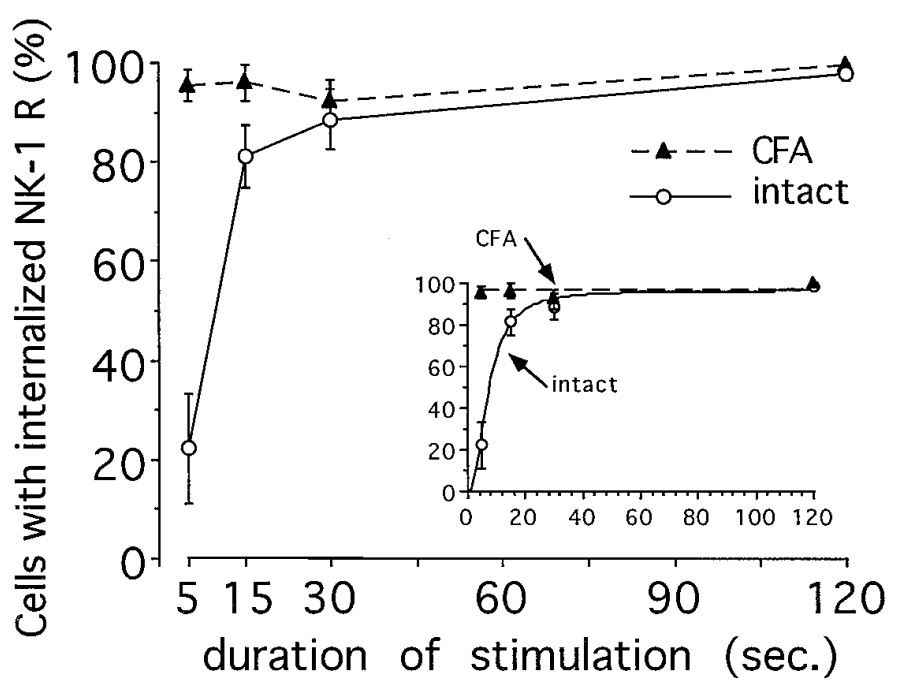

Figure 5. Percentage of NK-1 receptor-immunoreactive cells with internalized receptor in lamina I of the L4 segment after different durations of mechanical stimulation (pinch) of the hindpaw in normal rats and in rats $3 \mathrm{~d}$ after inflammation of the hindpaw was induced with CFA. Results are expressed as mean \pm SEM per group. In contrast to the effects of temperature, which produced a linear relationship between intensity of stimulation and number of neurons having internalized NK-1 receptors of (see Fig. 7), the relationship between the duration of the mechanical stimulation and the degree of internalization was not linear. For the intact animals, the Hill equation fit the data (see inset). In the setting of inflammation, the response plateaued.

segment) but no significant difference $(p=0.68)$ between the 15 and $30 \mathrm{sec}$ stimuli ( 81 and $88 \%$, respectively) or between the 30 and $120 \mathrm{sec}$ stimuli (88 and 98\%, respectively; $p=0.26$ ).

When we administered an NK-1 receptor antagonist, GR 205171 (20-25 min before the mechanical stimuli), we observed a significant decrease $(p<0.001$ of the number of cells that contained internalized NK-1 receptor. In the L4 segment the decrease averaged $78.2 \%$.

\section{Thermal stimulation}

Noxious thermal stimulation, produced by dipping the hindpaw in hot water, evoked a temperature-dependent increase in NK-1 receptor internalization in neurons of lamina I ipsilateral to the stimulus; however, in intact rats, we never found noxious heatinduced NK-1 receptor internalization in neurons located ventral to lamina I. Using the criterion of 20 endosomes per cell to define internalization, we found that the threshold for detecting significant increases in NK-1 receptor internalization of lamina I was $>45^{\circ} \mathrm{C}$. In fact, even $2 \mathrm{~min}$ at $45^{\circ} \mathrm{C}$ had no effect on the receptor distribution ( $<1 \%$ in lamina I of L4). When the temperature was increased to $48^{\circ} \mathrm{C} \sim 50-55 \%$ of neurons in lamina $\mathrm{I}$ of the $\mathrm{L} 4$ segment contained internalized NK-1 receptor; the percentage of cells increased to $70-75 \%$ at $50^{\circ} \mathrm{C}$ and to $95-100 \%$ at $52^{\circ} \mathrm{C}$. Statistical analysis revealed that there was a significant $(p<$ 0.001 ) effect of the intensity of the stimulus on NK-1 receptor internalization, and that the temperature-internalization relationship was linear in the range of $45-52^{\circ} \mathrm{C}$. (see Fig. 7). We also recorded a significant difference in the magnitude of internalization at different spinal segments $(p<0.001)$. Specifically, more neurons with internalized receptor were found in segments L4 and L5 than at more rostral or caudal segments (see Fig. $7 B$ ).

\section{Effects of stimulation in rats with hindpaw inflammation \\ Mechanical stimulation}

Noxious mechanical stimulation of the paw induced both a greater number of internalized cells in rats with inflammation than in intact rats and a shift in the dose-effect curve for stimulus duration (Figs. 1C, 5). The difference between the magnitude of receptor internalization in the intact rats and rats with inflammation was significant $(p<0.001)$. In the rats with inflammation, the $5 \mathrm{sec}$ stimulation induced near-maximal NK-1 receptor internalization; $95.5 \%$ of NK-1 receptor-immunoreactive neurons in lamina I cells of the L4 segment contained internalized receptor. At longer duration, the magnitude of internalization in the rats with inflammation was comparable, 96, 92, and 99\% for 15, 30, and $120 \mathrm{sec}$, respectively. Not surprisingly, we found that there was a significant difference $(p<0.001)$ between the magnitude of internalization in lamina I in the two groups for the 5, 15, and 30 sec stimulus but not for the $120 \mathrm{sec}$ stimulus.

As noted above, for intact rats, although the relationship between the magnitude of internalization and intensity of the stimulus was linear for temperature, this was not the case for the duration of the mechanical stimulus. Rather, we found that the curve for magnitude of internalization versus stimulus duration could be fit by the Hill equation (Fig. 5). The duration of stimulus that corresponded to $50 \%$ of internalization was estimated to be $7.2 \mathrm{sec}$, and the maximal value of internalization was estimated to be $95.5 \%$. Although the response plateaued with a much shorter duration stimulus in the CFA-treated rats, the maximal response did not differ from that in intact rats (Fig. 5).

The laminar distribution of cells that contained internalized NK-1 receptor after noxious mechanical stimulation also differed in intact rats and in rats with an inflamed hindpaw. Thus in intact rats, we rarely found changes ventral to lamina II (Fig. $1 B$ ); $<5 \%$ of NK-1 receptor-immunoreactive neurons in laminae III-VI responded to noxious mechanical stimulation by internalizing the receptor. In rats with inflammation, however, between 15 and $40 \%$ of the NK-1 receptor-immunoreactive neurons in laminae III-IV contained internalized receptor (Fig. $1 C$ ). The high variability that we recorded reflects the fact that there are relatively few NK-1 receptor-immunoreactive neurons in laminae III-IV (Fig. 6C). Although the large cells with dorsally directed dendrites are easily recognized, they are not common (Figs. 3, 4) (Bleazard et al., 1994; Liu et al., 1994; Brown et al., 1995). Finally, with the most prolonged noxious mechanical stimulus ( $2 \mathrm{~min}$ ) we also found changes in neurons of laminae V-VI. Thus in the L4 segment, this stimulus induced $\sim 50 \%$ of the neurons to internalize the NK-1 receptor. Even the most prolonged noxious mechanical stimulus was without effect on the NK-1 receptorimmunoreactive neurons in lamina $X$ (Fig. 4). This was also true for noxious thermal stimulation.

\section{Non-noxious mechanical stimulation}

In intact rats, non-noxious stimulation of the paw (brush for 2 min) never evoked NK-1 receptor internalization in neurons of the lumbar spinal cord (Fig. 6A). In contrast, when the same stimulus was applied to the inflamed hindpaw, we recorded considerable numbers of neurons that contained internalized NK-1 receptor. Specifically, brush stimulation evoked NK-1 receptor internalization in $\sim 75 \%$ of neurons in lamina I (Fig. $6 B$ ), and in $\sim 20 \%$ of neurons in laminae III-IV (Fig. $6 C$ ) of the L4 spinal segment. Brush stimulation also induced receptor internalization 


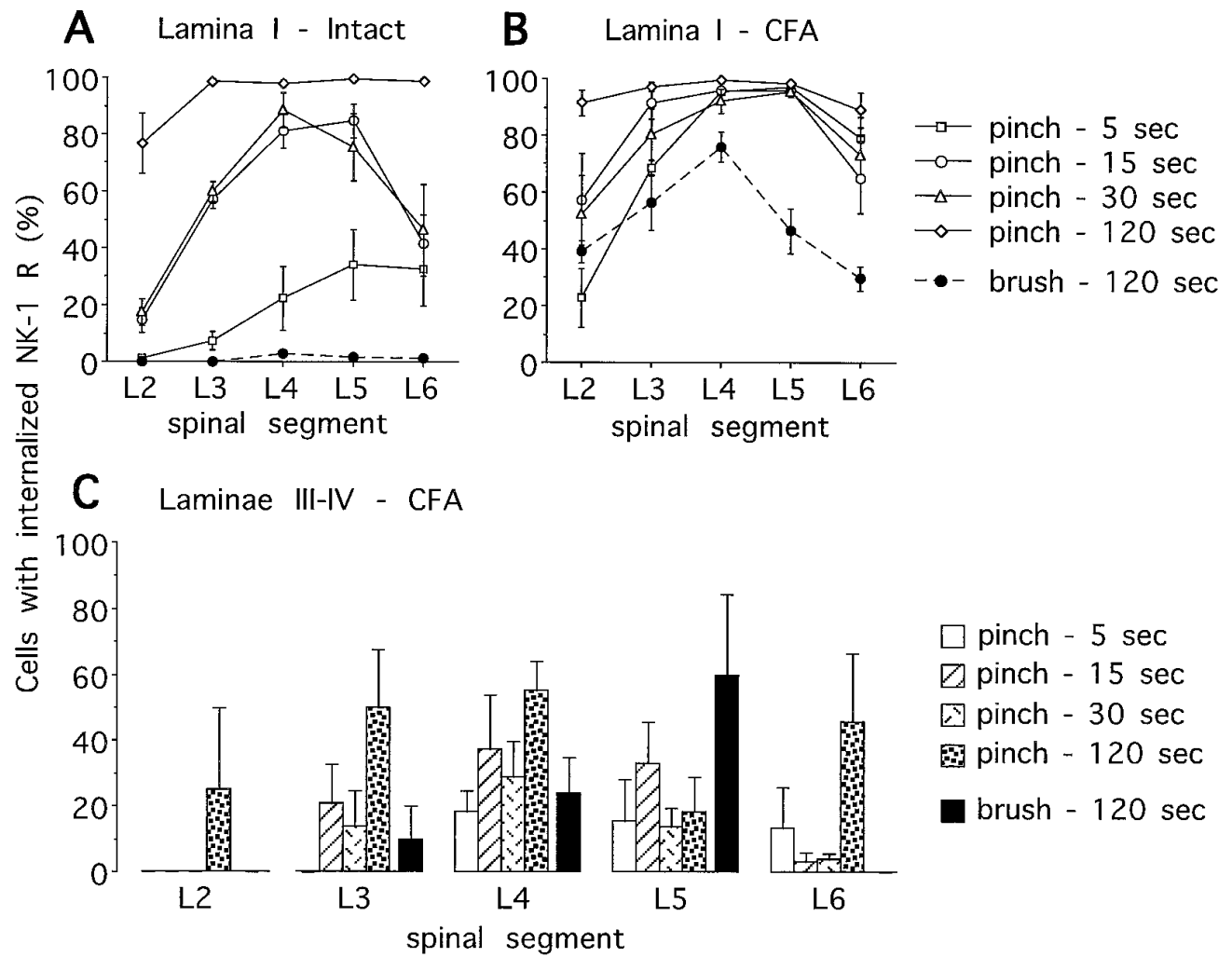

Figure 6. Percentage of cells in different laminae of the lumbar spinal cord and in different lumbar segments that contained internalized NK-1 receptor after mechanical stimulation of the hindpaw. Results are expressed as mean \pm SEM per group. Note that (1) a non-noxious mechanical stimulus (brush for $2 \mathrm{~min}$ ) did not induce internalization in intact rats $(A)$, but in rats with persistent inflammation $(3 \mathrm{~d}$ after CFA injection) this stimulus induced internalization in neurons of laminae and in laminae III-IV $(B, C)$; and (2) the magnitude of receptor internalization in rats with persistent inflammation did not differ with noxious mechanical stimuli (pinch) of different duration $(B, C)$. This contrasts with intact rats, in which the number of cell bodies with internalized receptor increases with the duration of the stimulus $(A)$.

Figure 7. Percentage of NK-1 receptor-immunoreactive spinal cord cells with internalized receptor after thermal stimulation of the hindpaw in intact rats and in rats with an inflamed hindpaw (3 d after CFA injection). Rats were stimulated for $2 \mathrm{~min}$ at 45 , 48,50 , or $52^{\circ} \mathrm{C}$. The results are expressed as mean \pm SEM per group. $A$, Percentage of internalized cells in lamina I of L4; $B$, rostrocaudal (L2-L6) distribution of neurons with internalized receptor. Note that (1) in neither intact rats nor in rats with inflammation did the $45^{\circ} \mathrm{C}$ stimulus induce NK-1 receptor internalization; (2) the number of internalized cells increased with temperature; and (3) there was no significant difference between the number of lamina I neurons with internalized receptor in the two groups of rats, regardless of temperature.
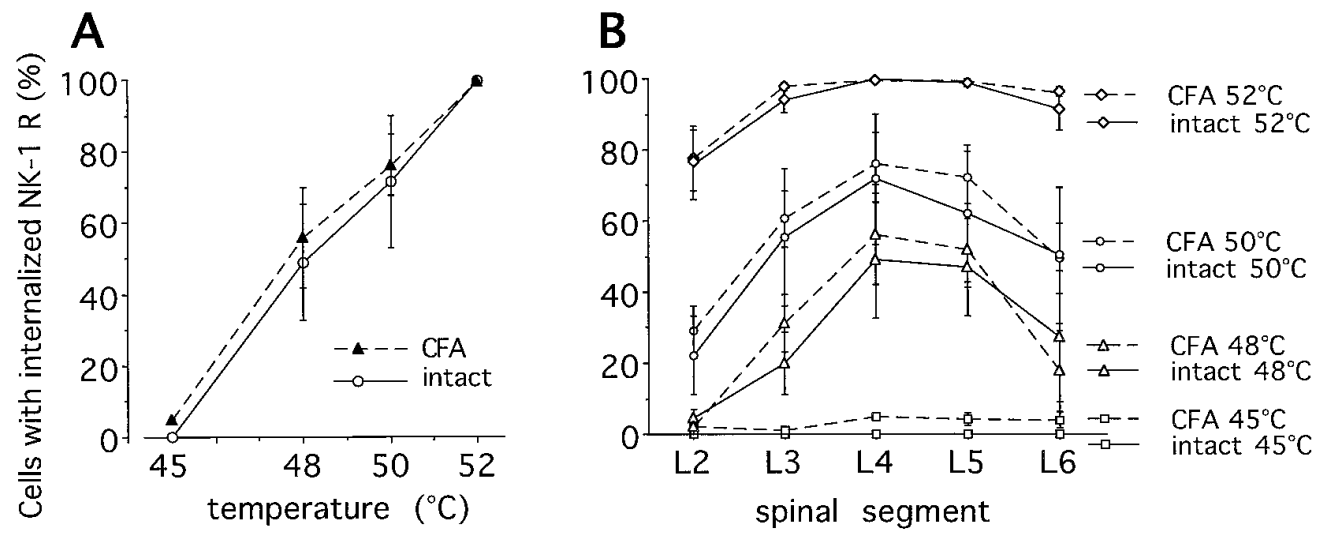

in lamina I neurons of the L2 and L6 segments, 39 and $29.6 \%$, respectively.

\section{Thermal stimulation}

As for mechanical stimulation, we found that internalization in response to noxious thermal stimuli increased in the setting of inflammation. The most striking change was observed with the $52^{\circ} \mathrm{C}$ stimulus, which after inflammation not only evoked internalization in $98-100 \%$ of lamina I neurons but also in $\sim 25 \%$ of neurons in laminae III-IV. In contrast to mechanical stimulation, however, neither the threshold for evoking internalization nor the slope of the curve relating magnitude of internalization and temperature changed in intact rats and in rats with inflammation ( $p=0.6$; Fig. 7A). Furthermore, the rostrocaudal distribution of internalized receptor at different spinal segments was the same in the two groups of rats (Fig. $7 B$ ).

\section{Temporal pattern of NK-1 receptor recycling in intact rats and in rats with inflammation}

In our previous studies, we found that the receptor recycled to the plasma membrane within $60 \mathrm{~min}$ of stimulation. To evaluate whether there are differences in the temporal pattern of receptor recycling in normal rats and in rats with inflammation, we assessed the magnitude of NK-1 receptor internalization at different times after noxious mechanical stimulation. To produce maximal internalization in the different groups of rats, we used the 2 min stimulus. As described above, the magnitude of internalization at $5 \mathrm{~min}$ after the stimulus was comparable in the two groups 

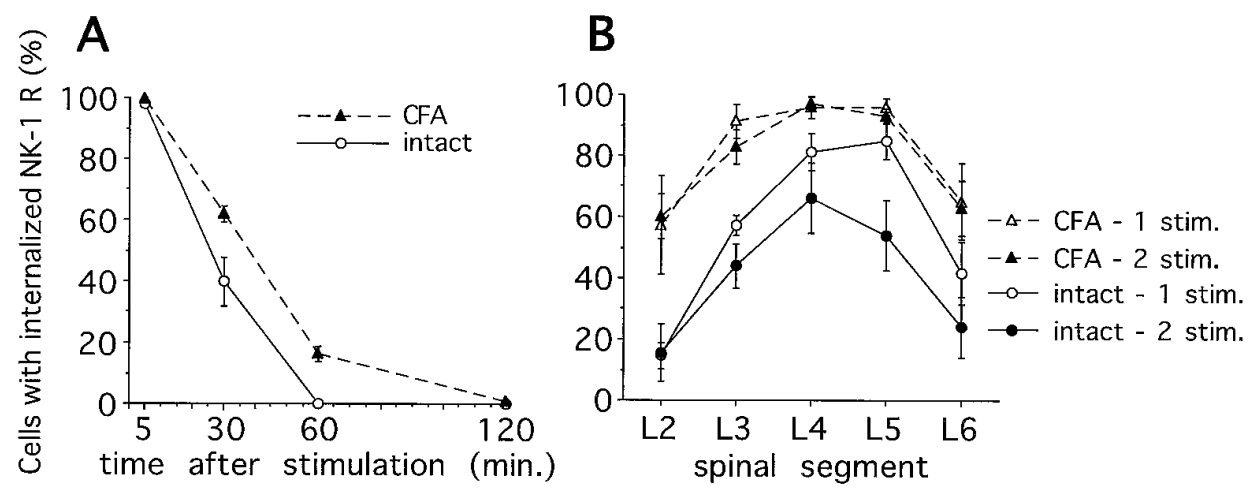

Figure 8. Percentage of NK-1 receptorimmunoreactive cells with internalized receptor in lamina I of the L4 segment. Results are expressed as mean \pm SEM per group. $A$, Time course of NK-1 receptor internalization from rats perfused at different times after hindpaw stimulation (pinch for $2 \mathrm{~min}$ ). The number of internalized cells is significantly greater in rats with an inflamed hindpaw than in intact rats at both 30 and $60 \mathrm{~min}$. $B$, Results of two successive mechanical stimuli; the second stimulus (pinch for $15 \mathrm{sec}$ ) was applied $1 \mathrm{hr}$ after the first, and the rats were perfused 5 min later. In the inflamed groups of rats, there is no difference ( $p=$ $0.7)$ in the magnitude of receptor internalization between the rats stimulated once and those stimulated twice. In intact rats there is a smaller number of cells with internalized receptor after the second stimulus, but the difference is only significant in the L5 segment $(p=0.015)$. of rats $(98 \%$ in L4 of intact rats, $99.75 \%$ in rats with inflammation). When we evaluated the spinal cords $30 \mathrm{~min}$ after the stimulus, however, we recorded a significantly greater magnitude of internalization of the receptor in neurons of lamina I cells $(p<0.0001)$ in the rats with inflammation compared with controls, 62 versus $40 \%$, respectively, in L4 (Fig. $8 A$ ). Whether this increase reflects continued release of SP after the stimulus is withdrawn is unclear. Sixty min after the stimulation, there was still significantly greater numbers of cells with internalized receptor in the rats with inflammation compared with the intact rats $(16.5 \% ; p<0.005)$. At $2 \mathrm{hr}$ the distribution of NK-1 receptor-LI in the rats with inflammation did not differ from that in stimulated controls or in unstimulated rats that received the CFA injection.

The preceding results establish that the receptor recycles to the membrane, but they do not establish that the receptor that is reinserted in the membrane is functional. Thus to assess the functional integrity of the membrane receptor at different times after stimulation, we also examined whether the receptor could be reinternalized by a second noxious stimulus. These studies were performed $60 \mathrm{~min}$ after the first stimulus, at which point most of the receptor recycles. The rats were perfused $5 \mathrm{~min}$ after the second stimulus, so that we could compare the magnitude of internalization to that produced by the same stimulus administered for the first time. In these studies, we used a stimulus of shorter duration $(15 \mathrm{sec})$, so that we could increase the detectability of differences in the response of the receptor at the $60 \mathrm{~min}$ time point. In rats with inflammation, we found no difference $(p=0.7)$ in the magnitude of internalization between the rats stimulated once for $15 \mathrm{sec}$ and those stimulated twice (Fig. 8B). We observed a tendency for a reduced magnitude after the second stimulus in intact rats, but only in the L5 segment did we find a statistically significant difference ( $p=0.015$; Fig. $8 B)$. These results indicate that the recycled receptor is, in fact, equally responsive to the stimulus conditions and will internalize on repeated stimulation.

\section{DISCUSSION}

In the present study we demonstrate that inflammation is associated with an upregulation of the NK-1 receptor, an increase in the number and distribution of dorsal horn neurons that internalize the NK-1 receptor in response to mechanical stimulation, and a decrease in the mechanical threshold for inducing internalization. The latter result implicates SP in the development of mechanical allodynia, whereby non-noxious stimulation can provoke withdrawal responses and pain behavior in the awake animal (Calvino et al., 1987a; Colpaert, 1987). We found less change in the magnitude and distribution of neurons that contained internalized NK-1 receptor in response to noxious thermal stimulation and no change in the thermal threshold for triggering the internalization. These results not only provide new evidence for a contribution of SP to the reorganization of dorsal horn circuits in the setting of persistent injury, but also indicate that the processing of nociceptive mechanical and thermal information is differentially modified in the setting of injury.

\section{NK-1 receptor internalization in normal rats: mechanical versus thermal stimulation}

Noxious pinch was the most potent stimulus for evoking internalization of the NK-1 receptor. In the setting of the inflammation, even the shortest duration noxious mechanical stimulus evoked near-maximal internalization. These results strongly suggest that SP is a neurotransmitter of high-threshold mechanoreceptors. Because we did not detect internalization at $45^{\circ} \mathrm{C}$, a temperature that activates polymodal nociceptors (Croze et al., 1976; Lynn and Carpenter, 1982), our results further suggest that this afferent is not the predominant source of SP, or that the level of SP release at this temperature is not high enough to induce internalization. Alternatively, the more profound effect of mechanical stimulation may reflect the synchronous activation of $\mathrm{A} \delta$ and $\mathrm{C}$ fibers, something that is less likely to occur with a thermal stimulus. Finally, it is possible that the release of SP depends on the pattern or frequency of firing of the SP-containing primary afferent fiber, and that these vary with mechanical and thermal noxious stimulation.

Because we only found heat-evoked internalization in deep dorsal horn in the setting of inflammation, our results do not agree with those of Radhakrishnan and Henry (1995), who found that NK-1 receptor antagonists block the response of deep dorsal horn neurons to noxious thermal stimulation in the normal animal. One possibility is that the population of neurons from which they made recordings is not representative of the majority of wide dynamic range neurons in the deep dorsal horn. Importantly, the electrophysiological analysis detects short-latency responses, which are probably driven by the direct synaptic inputs to the neurons. These may not be readily detected when the end point is internalization, because only a few receptors may internalize in 
response to a brief noxious heat pulse. It is also possible that the threshold for internalization that we used in this study (20 endosomes per cell) did not allow us to detect the functional consequences of small increases of SP release (Allen et al., 1997).

Despite these potential methodological explanations for the discrepancies, our results are consistent with several other studies that more directly monitored the release of SP. For example, using antibody-coated microelectrodes, Duggan and colleagues (1988) found, in the cat, that only at temperatures that produced clear inflammation $\left(>50^{\circ} \mathrm{C}\right)$ was there significant release of SP into the superficial dorsal horn. In the rat these authors found that a $48^{\circ} \mathrm{C}$ stimulus was sufficient (Lang and Hope, 1994). The latter results and ours are also consistent with those of Kuraishi et al. (1985, 1989), who reported that although a $45^{\circ} \mathrm{C}$ stimulus evoked the release of somatostatin into rat dorsal horn, SP was only detected when the temperature was at least $48^{\circ} \mathrm{C}$.

\section{NK-1 receptor internalization in the setting of inflammation}

The most important results in this paper concern the profound changes that occurred in the setting of inflammation. In our previous report that described an upregulation of the NK-1 receptor at different times after CFA-induced inflammation of the hindpaw, we suggested that the upregulation of receptor occurred in neurons that normally express the receptor. The use of fluorescence immunocytochemistry in the present study allowed a more accurate characterization of numbers of labeled neurons and confirmed that the number of NK-1 receptor-immunoreactive neurons per section did not differ in the different groups of rats. Furthermore, using electron microscopy we established that in the absence of stimulation, the receptor remained concentrated on the plasma membrane, even in the rats with an inflamed hindpaw and greatly upregulated receptor. Unless there is incredibly rapid turnover of the receptor, this result suggests that an $\mathrm{SP}-\mathrm{NK}-1$ receptor interaction does not come into play in the basal firing of spinal cord neurons. This is true despite the fact that SP levels and the affinity of the NK-1 receptor increase during the development of inflammation (Stucky et al., 1993). We conclude that the upregulation of the NK-1 receptor is only functionally manifested when a stimulus is superimposed on a background of inflammation-induced alterations in the dorsal horn.

In the setting of inflammation we found that noxious mechanical stimulation induced NK-1 receptor internalization to a much greater extent in neurons of the deep dorsal horn, and we recorded greater numbers of lamina I neurons in segments outside of the primary terminal region of afferents from the hindpaw, i.e., in L2 and L6. The most striking observation in the rats with inflammation of the hindpaw, however, was that even nonnoxious stimulation induced $\mathrm{NK}-1$ receptor internalization in dorsal horn neurons; this was never seen in intact rats. This provides the strongest evidence to date that the altered properties of dorsal horn neurons that occur in the setting of injury (Menétrey and Besson, 1982; Calvino et al., 1987b; Hylden et al., 1987, 1989) involve release of substance $P$ and interaction with dorsal horn neurons that express the NK-1 receptor. Because mechanical allodynia is a characteristic feature of persistent injury states (Calvino et al., 1987a), our results further suggest that SP contributes to the clinical manifestations of chronic inflammation.

There are several mechanisms through which these results could have been generated. In the normal animal, SP is concentrated in small-diameter, nociceptive afferents, and when there is inflammation, there is a cyclooxygenase-dependent sensitization of the terminals of the afferents, such that non-noxious stimuli can activate the afferents (Martin et al., 1988; Taiwo and Levine, 1990). Inflammation also induces a central sensitization of dorsal horn nociresponsive neurons, in which the receptive field of the dorsal horn neuron is increased, as is spontaneous activity, and the threshold for evoking activity in these neurons decreases (Menétrey and Besson, 1982; Calvino et al., 1987b; Hylden et al., 1987, 1989). Because C fibers do not project directly to neurons of the deep dorsal horn, an alternative explanation for the appearance of significant SP-mediated internalization is required. As noted previously, based on studies of Duggan et al. (1988) and Schaible et al. (1990), it is possible that diffusion of SP from superficial laminae to deep laminae is an important contributor. The fact that this is exacerbated in the setting of inflammation provides additional evidence in favor of this hypothesis. In the absence of significant diffusion of substance $\mathrm{P}$, it is likely that large-diameter A- $\beta$ fibers provide the non-nociceptive input to neurons that have undergone central sensitization. Although these large-diameter afferents do not synthesize SP in the normal rat, they do so in the setting of peripheral nerve injury (Noguchi et al., 1994) and inflammation (Neumann et al., 1996). This could provide a monosynaptic input to deep neurons that express the NK-1 receptor. Large fiber-mediated polysynaptic activation of SP-containing interneurons may also be involved. Thus, both small- and large-diameter afferents may be the source of the SP that induces NK-1 receptor internalization by non-noxious stimulation, the former to cell bodies and dendrites of marginal neurons and to the dorsally directed dendrites of lamina III neurons, the latter to neurons of the deep dorsal horn. It is also possible that a different afferent type (e.g., joint receptors) comes into play in the setting of inflammation, because of the sensitization that these afferents undergo after injection of CFA. Distinguishing between the contribution of peripheral and central sensitization is difficult, because any treatment that reduces peripheral sensitization of C-fiber afferents would concurrently reduce the inflammation. It may be possible to use electrical stimulation to activate fibers of different caliber selectively; however, the surgical procedure required to place the stimulating electrodes could itself induce internalization of the receptor.

Finally, despite there being a significant shift in the mechanical threshold for evoking NK-1 receptor internalization in the rats with hindpaw inflammation, we found little change in the response to noxious thermal stimulation. Only at the highest temperature $\left(52^{\circ} \mathrm{C}\right)$ was the magnitude of the response increased in rats with persistent inflammation, and only at this temperature did the distribution of neurons that contained internalized receptor change. Specifically at $52^{\circ} \mathrm{C}$, we observed NK-1 receptor internalization in about $25 \%$ of laminae III-IV neurons. These data suggest that an SP-mediated thermal allodynia does not develop in the setting of inflammation. Although this conclusion is somewhat at odds with the study of Ren et al. (1996), which reported that NK-1 antagonists attenuate hyperalgesia to thermal stimulation in CFA-treated rats, it is consistent with the report of Liu and Sandkühler (1995), which found enhanced responses of lamina I neurons to mechanical, but not to thermal, skin stimuli during superfusion with SP.

\section{Summary}

We have proposed that the pattern of neurons that internalize the NK-1 receptor in response to natural stimulation provides a functional measure of release of SP from primary afferent fibers, and possibly from SP-containing interneurons, and a "picture" of 
the distribution of neurons that are activated by SP. The results of the present study provide strong evidence that the population of neurons with which SP interacts changes dramatically in the setting of inflammation. We also demonstrate that mechanical stimulation is particularly effective in evoking the release of SP and inducing NK-1 receptor internalization. We suggest that the SP-NK-1 receptor-mediated changes that we have identified are critical contributors to the central sensitization of dorsal horn circuits that occurs in the setting of inflammation and thus to the allodynia and hyperalgesia that ensue after injury.

\section{REFERENCES}

Abbadie C, Besson JM, Calvino B (1995) C-Fos expression in the spinal cord and pain-related symptoms induced by chronic arthritis in the rat are prevented by pretreatment with Freund adjuvant. J Neurosci 14:5865-5871.

Abbadie C, Brown JL, Mantyh PW, Basbaum AI (1996) Spinal cord substance $\mathrm{P}$ receptor immunoreactivity increases in both inflammatory and nerve injury models of persistent pain. Neuroscience 70:201-209.

Allen BJ, Rogers S, Ghilardi JR, Menning PM, Kuskowski MA, Basbaum AI, Simone D, Mantyh PW (1997) Noxious cutaneous thermal stimuli induce a graded release of endogenous substance $\mathrm{P}$ in the spinal cord: imaging peptide action in vivo. J Neurosci 17:5921-5927.

Bleazard L, Hill RG, Morris R (1994) The correlation between the distribution of the NK1 receptor and the actions of tachykinin agonists in the dorsal horn of the rat indicates that substance $\mathrm{P}$ does not have a functional role on substantia gelatinosa (lamina II) neurons. J Neurosci $14: 7655-7664$.

Boeynaems JM (1980) Outlines of receptor theory. Amsterdam: Elsevier.

Brown JL, Liu H, Maggio JE, Vigna SR, Mantyh PW, Basbaum AI (1995) Morphological characterization of substance $\mathrm{P}$ receptorimmunoreactive neurons in the rat spinal cord and trigeminal nucleus caudalis. J Comp Neurol 356:327-344.

Calvino B, Crepon-Bernard M-O, Le Bars D (1987a) Parallel clinical and behavioral studies of adjuvant-induced arthritis in the rat: possible relationship with "chronic pain." Behav Brain Res 24:11-29.

Calvino B, Villanueva L, Le Bars D (1987b) Dorsal horn (convergent) neurones in the intact anaesthetized arthritic rat. I. Segmental excitatory influences. Pain 28:81-98.

Christensen BN, Perl ER (1970) Spinal neurons specifically excited by noxious thermal stimuli: marginal zone of the dorsal horn. J Neurophysiol 33:293-307.

Colpaert FC (1987) Evidence that adjuvant arthritis in the rat is associated with chronic pain. Pain 28:201-222.

Cridland RA, Henry JL (1988) Intrathecal administration of substance $\mathrm{P}$ in the rat: spinal transection or morphine blocks the behavioural responses but not the facilitation of the tail flick reflex. Neurosci Lett 84:203-208.

Croze S, Duclaux R, Kenshalo DR (1976) The thermal sensitivity of the polymodal nociceptors in the monkey. J Physiol (Lond) 263:539-562.

De Koninck Y, Henry JL (1991) Substance P-mediated slow excitatory postsynaptic potential elicited in dorsal horn neurons in vivo by noxious stimulation. Proc Natl Acad Sci USA 88:1344-11348.

De Koninck Y, Ribeiro-da-Silva A, Henry JL, Cuello AC (1992) Spinal neurons exhibiting a specific nociceptive response receive abundant substance P-containing synaptic contacts. Proc Natl Acad Sci USA 89:5073-5077.

Duggan AW, Hendry IA, Morton CR, Hutchison WD, Zhao ZQ (1988) Cutaneous stimuli releasing immunoreactive substance $\mathrm{P}$ in the dorsal horn of the cat. Brain Res 451:261-273.

Frenk H, Bossut D, Mayer DJ (1988) Is substance P a primary afferent neurotransmitter for nociceptive input? III. Valproic acid and chlordiazepoxide decrease behaviors elicited by intrathecal injection of substance P and excitatory compounds. Brain Res 455:240-246.

Henry JL (1976) Effects of substance P on functionally identified units in cat spinal cord. Brain Res 114:439-451.

Hökfelt T, Kellerth J-O, Nilsson G, Pernow B (1975) Substance P: localization in the central nervous system and in some primary sensory neurons. Science 190:889-890.

Hylden JL, Wilcox GL (1981) Intrathecal substance P elicits a caudallydirected biting and scratching behavior in mice. Brain Res 217:212-215.

Hylden JL, Nahin RL, Dubner R (1987) Altered responses of nocicep- tive cat lamina I spinal dorsal horn neurons after chronic sciatic neuroma formation. Brain Res 411:341-350.

Hylden JL, Nahin RL, Traub RJ, Dubner R (1989) Expansion of receptive fields of spinal lamina I projection neurons in rats with unilateral adjuvant-induced inflammation: The contribution of dorsal horn mechanisms. Pain 37:229-243.

Kuraishi Y, Hirota N, Sato Y, Hino Y, Satoh M, Akagi H (1985) Evidence that substance $\mathrm{P}$ and somatostatin transmit separate information related to pain in the spinal dorsal horn. Brain Res 325:294-298.

Kuraishi Y, Hirota N, Sato Y, Hanashima N, Takagi H, Satoh M (1989) Stimulus specificity of peripherally evoked substance P release from the rabbit dorsal horn in situ. Neuroscience 30:241-250.

Lang CW, Hope PJ (1994) Evidence for localized release of substance P within rat spinal cord evoked by physiological and electrical stimuli. Neuropeptides 26:413-419.

Liu H, Brown JL, Jasmin L, Maggio JE, Vigna SR, Mantyh PW, Basbaum AI (1994) Synaptic relationship between substance P and the substance P receptor: Light and electron microscopic characterization of the mismatch between neuropeptides and their receptors. Proc Natl Acad Sci USA 91:1009-1013.

Liu XG, Sandkühler J (1995) The effects of extrasynaptic substance P on nociceptive neurons in laminae I and II in rat lumbar spinal dorsal horn. Neuroscience 68:1207-1218.

Lynn B, Carpenter SE (1982) Primary afferent units from the hairy skin of the rat hindlimb. Brain Res 238:29-43.

Mantyh PW, Demaster E, Malhotra A, Ghilardi JR, Rogers S, Mantyh CR, Liu H, Basbaum AI, Vigna SR, Maggio JE, Simone D (1995) Receptor endocytosis and dendrite reshaping in spinal neurons after somatosensory stimulation. Science 268:1629-1632.

Martin HA, Basbaum AI, Goetzl EJ, Levine JD (1988) Leukotriene B4 decreases the mechanical and thermal thresholds of $C$-fiber nociceptors in the hairy skin of the rat. J Neurophysiol 60:438-445.

McCullagh P, Nelder JM (1989) Generalized linear models. London: Chapman and Hall.

Menétrey D, Besson JM (1982) Electrophysiological characteristics of dorsal horn cells in rats with cutaneous inflammation resulting from chronic arthritis. Pain 13:343-364.

Menétrey D, Giesler GJ, Besson JM (1977) An analysis of response properties of spinal cord dorsal horn neurons to nonnoxious and noxious stimuli in the spinal rat. Exp Brain Res 27:15-33.

Munro FE, Fleetwood WS, Parker R, Mitchell R (1993) The effects of neurokinin receptor antagonists on mustard oil-evoked activation of rat dorsal horn neurons. Neuropeptides 25:299-305.

Neumann S, Doubell TP, Leslie T, Woolf CJ (1996) Inflammatory pain hypersensitivity mediated by phenotypic switch in myelinated primary sensory neurons. Nature 384:360-364.

Noguchi K, Dubner R, De Leon M, Senba E, Ruda MA (1994) Axotomy induces preprotachykinin gene expression in a subpopulation of dorsal root ganglion neurons. J Neurosci Res 37:596-603.

Parker R, Fleetwood WS, Rosie R, Munro FE, Mitchell R (1993) Inhibition by NK2 but not NK1 antagonists of carrageenan-induced preprodynorphin mRNA expression in rat dorsal horn lamina I neurons. Neuropeptides 25:213-222.

Polley JS, Gaskin PJ, Perren MJ, Connor HE, Ward P, Beattie DT (1997) The activity of GR205171, a potent non-peptide tachykinin NK1 receptor antagonist, in the trigeminovascular system. Regul Peptides 68:23-29.

Radhakrishnan V, Henry JL (1995) Antagonism of nociceptive responses of the cat spinal dorsal horn neurons in vivo by the NK-1 receptor antagonists CP-96,345 and CP-99,994, but not CP-96,344. Neuroscience 64:943-958.

Ren K, Iadarola MJ, Dubner R (1996) An isobolographic analysis of the effects of $N$-methyl-D-aspartate and NK1 tachykinin receptor antagonists on inflammatory hyperalgesia in the rat. $\mathrm{Br} \mathrm{J}$ Pharmacol 117:196-202.

Schäfer MK, Nohr D, Krause JE, Weihe E (1993) Inflammationinduced upregulation of NK1 receptor mRNA in dorsal horn neurons. NeuroReport 4:1007-1010.

Schaible HG, Jarrott B, Hope PJ, Duggan AW (1990) Release of immunoreactive substance $\mathrm{P}$ in the spinal cord during development of acute arthritis in the knee joint of the cat: a study with antibody microprobes. Brain Res 529:214-223.

Stucky CL, Galeazza MT, Seybold VS (1993) Time dependent changes 
in Bolton-Hunter labeled ${ }^{125} \mathrm{I}$-Substance $\mathrm{P}$ binding in rat spinal cord following unilateral adjuvant-induced peripheral inflammation. Neuroscience 57:397-409.

Taiwo YO, Levine JD (1990) Effects of cyclooxygenase products of arachidonic acid metabolism on cutaneous nociceptive threshold in the rat. Brain Res 537:372-374.

Thompson SW, Dray A, Urban L (1994) Injury-induced plasticity of spinal reflex activity: neurokinin-1 receptor activation and enhanced Aand $\mathrm{C}$-fiber mediated responses in the rat spinal cord in vitro. J Neurosci 14:3672-3687.

Tiseo PJ, Adler MW, Liu-Chen LY (1990) Differential release of substance $\mathrm{P}$ and somatostatin in the rat spinal cord in response to noxious cold and heat; effect of dynorphin A(1-17). J Pharmacol Exp Ther 252:539-545.
Vigna SR, Bowden JJ, McDonald DM, Fisher J, Okamoto A, McVey DC, Payan DG, Bunnett NW (1994) Characterization of antibodies to the rat substance $\mathrm{P}(\mathrm{NK}-1)$ receptor and to a chimeric substance $\mathrm{P}$ receptor expressed in mammalian cells. J Neurosci 14:834-845.

Yaksh TL, Jessell TM, Gamse R, Mudge AW, Leeman SE (1980) Intrathecal morphine inhibits substance $\mathrm{P}$ release from mammalian spinal cord in vivo. Nature 286:155-157.

Yamamoto T, Yaksh TL (1992) Effects of intrathecal capsaicin and an NK-1 antagonist, CP,96-345, on the thermal hyperalgesia observed following unilateral constriction of the sciatic nerve in the rat. Pain 51:329-334.

Yamamoto T, Shimoyama N, Mizuguchi T (1993) Effects of intrathecal FK888, a novel dipeptide NK1 receptor antagonist, on the formalin test in the rat. Neurosci Lett 161:57-59. 